\title{
EXCESSIVE SCREEN MEDIA EXPOSURE AND LANGUAGE DELAY IN THE DEVELOPMENT OF INFANTS AND TODDLERS - THREE CASE REPORTS
}

Senka Simonović ${ }^{1}$ and Darko Hinić ${ }^{2}$

${ }^{1}$ University of Kragujevac, Faculty of Medical Sciences, Serbia

${ }^{2}$ University of Kragujevac, Faculty of Science \& Faculty of Philology and Arts, Serbia

\section{PREKOMERNA IZLOŽENOST DIGITALNIM MEDIJIMA I KAŠNJENJE U RAZVOJU GOVORA KOD DECE RANOG UZRASTA - TRI STUDIJE SLUČAJA \\ Senka Simonović1 ${ }^{1}$ Darko Hinić ${ }^{2}$ \\ ${ }^{1}$ Univerzitet u Kragujevcu, Fakultet medicinskih nauka, Srbija}

${ }^{2}$ Univerzitet u Kragujevcu, Prirodno-matematički fakultet, Filološko-umetnički fakultet, Srbija

\begin{abstract}
Early exposure to digital media has become an integral part of everyday life, which is frequently being reported as one of potential risk factors for a number of developmental disorders, including language development in infants and toddlers. The current article represents introduction to a research study which will be dealing with a potential link between the risk of language delay and excessive screen media time in children. With this in mind, we will present three case reports involving young children who experienced a language delay, but did not have any health problems diagnosed, nor did they have any of the physical high-risk factors for language and other developmental disorders detected. What these three children have in common is the fact that they were all excessively exposed to digital media during the first two years of life. The existing empirical findings suggest that different forms of digital content may be overstimulating for the developing brain, which is true both for active and background screen viewing. Moreover, screen time may be seen as a distraction from other more developmentally important activities. Keeping parents informed about a potential negative influence of prolonged media exposure can prompt parents to make informed decisions about whether and to what extent they will expose their children to digital media in the earliest period of their development.
\end{abstract}

Keywords: infants and toddlers; language delay; screen media exposure.

\section{SAŽETAK}

Rano izlaganje digitalnim sadržajima postalo je sastavni deo naše svakodnevice, a sve češće se pominje kao jedan od potencijalnih faktora rizika za brojne razvojne probleme, uključujući $i$ razvoj govora kod dece ranog uzrasta. Ovaj rad predstavlja uvod u istraživačku studiju koja će se baviti ispitivanjem potencijalne veze između rizika od kašnjenja u razvoju govora i prekomernog gledanja digitalnih medijskih sadržaja kod dece. U tu svrhu prikazali smo analizu tri studije slučaja dece kod kojih je došlo do kašnjenja u razvoju govora, a kod kojih nisu dijagnostikovani zdravstveni problem, niti identifikovani bilo koji od poznatih fizičkih faktora, rizičnih za razvoj poremećaja govora ili neki drugi razvojni poremećaj. Ono što je zajedničko za sva tri deteta je da su u toku prve dve godine života bila prekomerno izložena sadržajima digitalnih medija. Postojeći empirijski nalazi sugerišu da medijski sadržaji mogu biti preterano stimulativni za razvoj moždanih struktura, pri čemu to važi i za aktivno i za pasivno gledanje sadržaja. Takođe, ovi sadržaji mogu predstavljati distrakciju od drugih, važnih i razvojno podsticajnih aktivnosti. Informisanost o potencijalno negativnom uticaju dugotrajne izloženosti medijima može podstaći roditelje da donose informisane odluke koliko će i da li će izlagati svoju decu digitalnim medijima u najranijem periodu razvoja.

Ključne reči: deca ranog uzrasta, kašnjenje u govoru, izlaganje digitalnim medijima. 


\section{INTRODUCTION}

The first three years of life represent the critical period for the development of the child's brain, their cognitive abilities and speech. Infants are born with brains that are not fully developed yet, and research showed that the brain of a newborn triples in size during the first two years of life, and that this growth occurs in direct response to external early life experiences and stimulation $(1,2)$. The environment in which the child grows as well as the contents to which they are exposed may either stimulate or inhibit their development in such a sensitive period. The contents that we watch via digital media (television, smartphones, computers ...) have become an integral part of our everyday life, as well as our children's lives. In this context, the screen time concept, typically defined as "time spent with any screen, including smartphones, tablets, television, video games, computers or wearable technology" (3), holds a prominent place in research. Tablets and smartphones are particularly important because different forms of digital content have now become accessible everywhere, at any time. Although infants are capable of imitating what they see on a screen, children do not learn from television as well as they do from direct, live experiences (1). The development of language certainly holds a special place in this development.

\section{Language development}

Speech comprehension and functional communication are some of the essential functions that a child should master by the age of three. Within the period of 18 to 20 months, an infant should produce from 50 to 100 words (4). At the age of two, a normal speech development would require a vocabulary of a minimum of 50 words, along with combining shorter sentences or two-word phrases that are understandable to their environment. Typical problems that may slow down the speech development form the intricate relationship between the biological development and social environment (5). Those may be hearing impairment, complications during pregnancy or delivery (e.g., birth asphyxia), oropharyngeal malformation, or family history of speech-language difficulties, a low level of parental education, multilingual environment, and inadequate stimulation (5-7). Within this context, potential influence of digital content use, or digital media in general, has been increasingly considered in the last few decades.

When it comes to children, spending too much time in front of digital screens makes an impact on their communication with parents and social environment. The American Academy of Paediatrics has warned of the existence of numerous problems that are associated with excessive exposure to digital media, such as difficulties with sleep, speech, aggressive outbursts, and lower school achievement (8). The latest recommendation of the World Health Organisation is that children should not be exposed to digital media by the age of two, and after the age of two screen time should be no longer than one hour per day (9). These recommendations are based on the data obtained by a number of studies indicating that screen time does not only affect language acquisition, but also children's cognitive development, their physical activity, sleep patterns, attention, and ability to learn. Many studies point to the link between prolonged exposure to digital content with later talking times, together with language comprehension difficulties $(10,11)$. The majority of the studies that assessed the effects of long television exposure on language development in toddlers reported a higher risk of delays in expressive language (12). Another potential problem in language development is the fact that smartphones and tablets nowdays offer various topics in different languages. This exposure is expected to exert effects on children's first or foreign language development, due to sending mixed signals to the child (13). Language development is also connected with attention development, in such a way that the longer the children's exposure in the first three years of life, the greater the chance that they will also have attention difficulties (14). Even the background screen media (exposure without actively viewing or using the media, mainly to do with TV sets or computers), can have a significant effect on reduced attention during play or other children's activities, as well as the quality of their interaction with parents $(1,15)$.

This paper is an introduction to a research study that will be dealing with the investigation into a potential link between language delay and other problems in the early development of children, and prolonged screen time, i.e., excessive exposure to all forms of digital content. Within the current study, we will present three short case reports that have the following in common: parents sought the assistance of a psychologist due to delayed language development of their child in all three case reports, and it was determined that all the children were significantly exposed to various forms of digital content. What is important to underline is that none of the children had any health problems diagnosed that could influence the development of basic abilities, including the ability to speak. Keeping parents informed about a potential negative link between their children's exposure to digital media in this developmental period and some cognitive difficulties may prompt parents to make informed decisions about whether and to what extent they will expose their children to the digital media in the earliest period of their development.

\section{CASE REPORTS}

\section{Case 1}

Visit 1: A boy, aged three years and three months. Visits a psychologist due to delayed speech and language development. The firstborn child, the pregnancy was normal. Delivered at 39 weeks of gestation by natural childbirth with no complications. The Apgar score was 9 (10 being the maximum). No record of prior serious illnesses.

Early psychomotor development: Age-appropriate gross motor skills well-developed. Fine motor skills below the expected level. Sphincter control not acquired. Sleep and appetite are normal. Partly independent in basic self-care activities. 
First meaningful words spoken at 12 months, with language development still being delayed. Uses 10 meaningful words actively. Does not form two-word phrases. Receptive language developed, understands commands, and performs them.

Child development was assessed by means of the Scale of Psychomotor Development of Children (the Brunet-Lézine scale), whose main purpose was to evaluate the child's motor activity (i.e., posture and hand-eye coordination) and social interactions (language and sociability) (16). The results showed a twenty-month developmental delay for this age. The delay was particularly present in the language development and hand-eye coordination domains.

Social interaction: Included in the regular peer group since the age of two. Sparse interaction with other children, does not initiate contact, but interacts with them once the interaction is established. Mainly plays independently. Symbolic play not developed. Typically arranges toys in a stereotypical manner or throws them. Hypervigilant during play.

Media exposure: Watches cartoons approximately four hours per day. The cartoons are in Serbian and English. The parents state that the boy was passively exposed to the screen throughout the day at the age of two.

Family status: Parents divorced. Lives with his mother, sees his father regularly. In the course of growing up, he was frequently exposed to stressful family situations. The parents disclaim any genetic disorders of significance. They had secondary-level education.

Current status: The child is five years old, with dysphasia. His sentences are short, frequently incomprehensible to the wider social environment. At this point, the boy was undergoing speech-language therapy, but with infrequent visits to the therapist. The boy is still hypervigilant. Does not initiate contact with other children. Occasionally displays aggressive outbursts towards his mother and other children in his peer group. He is still exposed to the digital media for more than three hours per day.

\section{Case 2}

Visit 1: A girl, aged two years and five months. Visits a psychologist due to delayed speech and language development. The firstborn child, the pregnancy was normal. Delivered at 40 weeks of gestation by natural childbirth with no complications. The Apgar score was 9. No record of prior serious illnesses.

Early psychomotor development: Started walking at 11 months. The walk was steady. Age-appropriate gross motor skills well-developed. Sphincter control not acquired. Did not master age-appropriate basic self-care activities. Sleep and appetite normal.

Receptive language partly developed. Understands and performs simple commands that are used every day. First meaningful words spoken at 12 months. She could produce four words that she actively used, mostly in English. According to her mother, the toddler could produce more words at one point but then she stopped using them. At times repeats a word that her mother utters, in the form of echolalia. Functional speech not developed. Communicates non-verbally, through gestures. Play below the age-appropriate level, predominantly stereotyped. The psychological assessment via the Brunet-Lézine scale suggests a thirteen-month developmental delay for this age. The delay was specifically dominant in the language development domain. Does not establish eye contact during the visits. Does not respond to her name.

Social interaction: Not included in the regular peer group. Does not have frequent contact with other children.

Media exposure: Watches cartoons almost the entire day. The cartoons are mainly in English, occasionally in German and Russian.

Family status: Lives in a three-member family, with her parents. Family relationships are adequate. The parents disclaim any genetic disorders of significance. They had secondary-level education. Financial problems present within the family.

Current status: The child is five and a half years old. Visits a special educator and a speech therapist for treatments, but irregularly due to financial family problems. Visits a psychologist for check-ups every three months. Forms shorter sentences. Expressive dysphasia. Uses Serbian, English, and occasionally German words. The sentences are ungrammatical, often incomprehensible to the social environment. The girl is hypervigilant. Has difficulty in focusing her attention and maintaining it. Increased motor activity. Emotional maturity below the age-appropriate level. Negativism still increased. Displays temper tantrums when thwarted. She is still exposed to the digital media for more than an hour a day. Included in the regular peer group, makes and initiates contact with other children, but has difficulty in adhering to the group rules.

\section{Case 3}

Visit 1: A two-year-old boy. The mother takes him to a psychologist for psychological assessment because of speech-language delay. The second-born child, the pregnancy was normal. Delivered at 40 weeks of gestation via Csection due to the previous labour complications. The Apgar score was 10 . No record of prior serious illnesses.

Early psychomotor development: Started walking at 12 months. The walk was steady. Skilled motor performance. Sphincter control not acquired.

Receptive language at the basic level. Understands and performs simple commands. Does not use a single meaningful word. First meaningful words appeared at the age of one; yet the boy stopped using them. Does not establish eye contact. Understands simple commands solely. Does not imitate 
animals, which he could do when he was 12 months. Does not show interest in toys, play below the age-appropriate level. Typically puts objects into his mouth or throws things. Symbolic play not developed.

The psychological assessment via the Brunet-Lézine scale suggests a fourteen-month developmental delay for this age. The delay was specifically dominant in the language development and hand-eye coordination domains.

Social interaction: Not included in the peer group. Does not have frequent contact with his peers.

Media exposure: The mother states that since 14 months old the child had been spending the majority of the day on a smartphone, tablet and in front of the TV, watching cartoons. At that time, the boy stopped using the words that he had been using before.

Family status: Lives in a four-member family, with his parents and his elder brother. Family relationships are adequate. The parents have a university degree. They disclaim any genetic disorders of significance.

Current status: The boy is three years and five months old. Forms shorter sentences. His vocabulary has significantly expanded. Play is being developed adequately. Able to focus his attention and maintain it. He was undergoing intensive treatments with a speech therapist, including a sensory room for a year. The treatments are no longer necessary. His exposure to the digital media has been completely limited. Included in the regular peer group. Adjusted adequately, accepts the company of other children, but prefers individual activities.

\section{DISCUSSION}

Regarding the case reports we have presented in this paper, it is important to underline that these children were born healthy, the pregnancies and deliveries were normal, and according to the physical criteria they do not fall into the risk category in terms of language development, or any other developmental disorder. This is confirmed by the fact that all the children are still healthy, with no medical history of previous major illnesses. What is also significant to note is that there were no speech and language disorders in any of the family, nor were there any other hereditary developmental difficulties. Finally, what is common for all the three children is that they spent a significant amount of time in front of a screen during the first two years of life.

It is important to underline that we can by no means claim any causal relationships between excessive screen media exposure and language delay in young children based on the presented case reports. However, they may serve as a basis for further empirical, scientifically rigorous investigations into the stated hypotheses. When we consider the theories and the existent empirical findings, there are two possible interpretations of the possible negative impact of screen time on these children's development. The first one would be supported with the idea that quick scene changes, flashing lights, bright colours and loud sounds may be overstimulating for the developing brain (1). This effect is not only relevant for active, but also for background (passive) viewing (15). This can be noticed in the boy from Case Report 1 presented in this paper, who spent four hours per day actively watching cartoons, but was passively exposed to a digital content for the rest of the day. Prolonged background TV exposure has been proven quite detrimental to language development, attention, and the overall cognitive development (17), while background viewing alone may inflict considerable harm to play development (18). This is true for all the three children from our study as well, whose play was considerably impoverished, stereotyped, with no functional use of toys. Likewise, all the three children watched cartoons in different languages. As stated in the Introduction, watching various content in different languages when the child has not yet developed their mother tongue may create obstacles to these children's language development (13), which is evident in the girl, from Case Report 2, who predominantly repeats words in the English language.

The second interpretation regarding the detrimental effect of screen time may be the fact that it creates a distraction from other more developmentally important activities (1). With regard to the children included in this study, the first child spent four hours a day watching cartoons actively, whereas the other two spent almost the entire day doing this. It follows from this that a larger portion of the day when a child is awake is spent on activities that may not be stimulating for their development, thereby preventing them to spend time on different content that may be so. As already stated, early-life experiences are crucial for the normal development of the child's brain, and it is of critical importance to educate parents about potentially beneficial and potentially harmful experiences to the development of their children.

The most significant difference between these three children upon detection of the language delay lies in the manner in which the treatments were administered. There are studies implying that untreated speech and language delay can persist in $40 \%-60 \%$ of the children and that these children are at a higher risk of social, emotional, behavioural, and cognitive problems in adulthood (7). It is clear that the greatest progress has been traced in the third child, whose screen time was completely restricted after the diagnosis, accompanied with regular treatments with a speech therapist. In the first two cases, screen time was not limited but only reduced. Inadequate family relationships, along with financial difficulties, may be disadvantageous to successful implementation of the language disorder treatment; therefore, they are commonly stated as potential risk factors $(7,13)$. Family stress was present with regard to one of the two children with slower progress, while with the other, those were financial problems in the family. Parents who are overly preoccupied with these problems may be less motivated to take an active part in their child's language development and are thus more likely to reach for screen time use as a babysitter (11). In a similar vein, the connection with parental educational level has also 
been cited as a potential factor in the literature; thus, greater progress was detected in relation to the third child, whose parents had a higher degree. Highly educated parents are less likely to engage in screen activities because they are aware that such activities may disturb the child's development (12). They also engage their children more, use more complex words, thereby encouraging their children's language skills development (7). Consequently, certain family activities may have an ameliorating effect on the negative impact of increased screen time, such as frequent reading to children (19).

Nevertheless, it is essential to draw attention to the fact that not all forms of digital content are the same, and that media content and the context in which they are followed are often more important than the actual amount of time spent watching the media (1). Watching content aimed at older children or adults may have a negative influence on the development of infants, especially below 6 months old (20). In contrast to this, programmes with digital content designed especially for educational purposes differ from general digital programmes because they involve simple narrative structures, as well as contain pauses for children to respond (12). Similarly, it is important to state that language acquisition may only be achieved in two-way interaction which stimulates the expressive component of speech that is absent in prolonged screen time (12). A potentially positive impact and reduced harmfulness are achieved when screen time is spent with their parents, discussing the content with the child, connecting the screen content with everyday life (21). Finally, impoverished contact with other children may be another factor negatively influencing the communication skills development, which is noticeable in the children described in these case studies. Despite the interactivity of some of the media content, real-life social interactions are still irreplaceable in terms of the development of cognitive abilities.

\section{CONCLUSION}

Early and prolonged screen exposure may potentially cause delayed language development in children. Further research within this area of study, specifically those that will be particularly focused on media content and the context in which they are followed, besides screen time, may be of special importance to collecting more conclusive data based on which clear guidelines can be devised, and educational trainings for parents of infants and toddlers may be organised.

\section{REFERENCES}

1. Christakis DA. The effects of infant media usage: What do we know and what should we learn? Acta Paediatr. 2009; 98(1): 8-16. DOI: 10.1111/j.1651-2227.2008.01 027.x

2. Nelson CA, Bosquet M. Neurobiology of fetal and infant development: implications for infant mental health. In CH. Zeanah, Jr. (Ed.), Handbook of Infant Development. 2nd ed. (pp. 37-59). New York: The Guilford Press, 2000.
3. Canadian Paediatric Society. Screen time and young children: Promoting health and development in a digital world. Paediatr Child Health. 2017; 22(8): 461-468. DOI: $10.1093 / \mathrm{pch} / \mathrm{pxx} 123$

4. Simms MD. Language development and communication disorders. In RM. Kliegman, BF. Stanton, J. St. Geme, NF. Schor (Eds.), Nelson textbook of pediatrics. 20th ed. (pp 207-216). Philadelphia: Elsevier, 2016.

5. Shriberg LD, Kent RD, Karlsson HB, McSweeny JL, Nadler CJ, Brown RL. A diagnostic marker for speech delay associated with otitis media with effusion: Backing of obstruents. Clin Linguist Phon. 2003; 17(7): 529547. DOI: $10.1080 / 0269920031000138132$

6. Wooles N, Swann J, Hoskison E. Speech and language delay in children: A case to learn from. Br J Gen Pract. 2018; 68(666): 47-48. DOI: 10.3399/bjgp17X694373

7. Sunderajan T, Kanhere SV. Speech and language delay in children: Prevalence and risk factors. J Family Med Prim Care. 2019; 8(5): 1642-1646. DOI: 10.4103/ jfmpc.jfmpc_162_19

8. American Academy of Pediatrics. Media and young minds. Pediatrics 2016; 138(5): e20162591 DOI: 10.1542/peds.2016-2591.

9. World Health Organization. Guidelines on physical activity, sedentary behaviour and sleep for children under 5 years of age. World Health Organization, 2019. Retrieved January 30, 2021, from https://apps.who.int/iris/ handle/10665/311664

10. Duch H, Fisher EM, Ensari I, Font M, Harrington A, Toromino C, et al. Association of screen time use and language development in Hispanic toddlers: a crosssectional and longitudinal study. Clin Pediatr. 2013; 52(9): 857-865. DOI:10.1177/0009922813492881

11. Zimmerman FJ, Christakis DA, Meltzoff AN. Associations between media viewing and language development in children under age 2 years. J Pediatr. 2007; 151(4): 364-368. DOI: 10.1016/j.jpeds.2007.04.071

12. Maulana MS, Gunardi H. Risk of language delay in toddlers with prolonged screen time: Evidence based case report. J Early Child Islamic Educ Study. 2020; 1(1): 34-48. DOI: 10.33853/jecies.v1i1.53

13. Alroqi HS. The relationship between screen media exposure and early language development. Unpublished doctoral dissertation, University of Manchester, UK, 2018.

14. Christakis DA, Zimmerman FJ, DiGiuseppe DL, McCarty CA. Early television exposure and subsequent attentional problems in children. Pediatrics, 2004; 113(4): 708-713. DOI: 10.1542/peds.113.4.708

15. Setliff AE, Courage ML. Background television and infants' allocation of their attention during toy play. Infancy 2011; 16: 611-639. DOI: 10.1111/j.15327078.2011.00070.x

16. Cardoso F, Formiga C, Bizinotto T, Tessler RB, Neto FR. Concurrent validity of the Brunet-Lézine scale with the Bayley scale for assessment of the development of preterm infants up to two years. Rev Paul Pediatr. 2017; 35(2): 144-150. DOI: 10.1590/1984-0462/;2017;35;2; 00005 
17. Lapierre MA, Piotrowsky JT, Linebarger DL. Background television in the homes of US children. Pediatrics 2012; 130(5): 839-846. DOI: 10.1542/peds.20112581

18. Schmitt ME, Pempek TA, Kirkorian HL, Lund AF, Anderson DR. The effect of background television on the toy play behaviour of very young children. Child Dev. 2008; 79(4): 1137-1151. DOI: 10.1111/j.14678624.2008.01180.x

19. Taylor G, Monaghan P, Westermann G. Investigating the association between children's screen media exposure and vocabulary size in the UK. J Child Media.
2018; 12(1): 51-65. DOI: 10.1080/17482798.2017. 1365737

20. Tomopoulos S, Dreyer BP, Berkule S, Fierman AH, Brockmeyer C, Mendelsohn AL. Infant media exposure and toddler development. Arch Pediatr Adolesc Med. 2010; 164(12): 1105-1111. DOI: 10.1001/archpediatrics. 2010.235

21. Linebarger DL, Walker D. Infants' and toddlers' television viewing and language outcomes. Am Behav Sci. 2005; 48(5): 624-645. DOI: 10.1177/0002764204271 505 